\title{
Information System for Internship and Final Project Management Based on Laravel Framework
}

\author{
$1^{\text {st }}$ Yudhi Prabowo Kusuma \\ Dept. Electrical Engineering \\ Universitas Sebelas Maret \\ Surakarta, Indonesia \\ yudhie123@gmail.com
}

\author{
$2^{\text {nd }}$ Sutrisno \\ Dept. Electrical Engineering \\ Universitas Sebelas Maret \\ Surakarta, Indonesia \\ sutrisno@staff.uns.ac.id
}

\author{
$3^{\text {rd }}$ Muhammad Hamka Ibrahim \\ Dept. Electrical Engineering \\ Universitas Sebelas Maret \\ Surakarta, Indonesia \\ hamka@staff.uns.ac.id
}

\begin{abstract}
The Development of Portal Elektro Information System is carried out to create solutions for administrative problems related to Internship and Final Project, especially students, lecturers, and Electrical Engineering staff. Moreover it is an effort to improve the quality of the system to be more innovative and support the needs of Electrical Engineering study program. The System of Portal Elektro covers student needs to carry out internship or final project, starting from implementation guidelines, proposal writing, until becomes final report. This information system is developed with Rapid Application Development method, and use Laravel framework with the concept of MVC (Model, View, Controller) which can separate application based on application components, such as: manipulation data, controller, and user interface. With the RAD method and Laravel framework, application development can be done quickly and structured making it easier for further development in the future. The developed system has been successfully tested and applied in the Electrical Engineering study program at UNS and is planned to be implemented in several other study programs.
\end{abstract}

Keywords-Information system, Laravel, MVC, RAD

\section{INTRODUCTION}

An information system is a set of components that connect, collect, process, store, and dis tribute information to support decision making and monitoring in an organization. Currently, information systems cannot be separated from computer technology which is developing very rapidly along with increas in gly complex human needs [1].

The use of a computerized system is expected to minimize errors made by humans and can streamline the time to complete work quickly and accurately [2]. In addition, a computerized system can function as a data manager to present interactive and communicative information. Do not miss the academic system of a university where the academic information system is very vital in a university, namely in the form of data information on students, lecturers, staff, list of grades, courses, etc.

The academic system can be implemented in the form of a web, so that students and lecturers can easily access it using a cellphone even if there is an intemet connection. The web is created using the PHP programming language and SQL database which are open source programs and are very commonly used [3].

The current Information System can only be used for Intemship administration, while for the Final Project using a blog made using the Google site, it is necessary to develop an information system that can handle Intemship and Final Projects in one container so that the data used more efficient.

This Information System use Laravel framework with the MVC concept (Model, View, Controller) which can separate applications based on application components, such as manipulating data, controllers, and user interfaces. So that model components are easier to implement, test, and maintain, because all access to the model goes through these components. The main goal of developing using the Laravel framework is to help developers work on applications faster. In addition to using the Laravel framework, the development of this information system uses the Rapid Application Development (RAD) development method.

The development of the Information System is an effort to improve the quality of the system to be more innovative and can support the needs of the Electrical Engineering study program. This system consists of an administrative system Internship and Final Projects for Electrical Engineering students. This system covers student needs to carry out internship and final project, from implementation guidelines and proposal writing, to final report.

\section{RESEARCh Method}

\section{A. Software Development Method}

Internship and Final Project Management Information System is developed by using the Rapid Application Development (RAD) with the following steps:

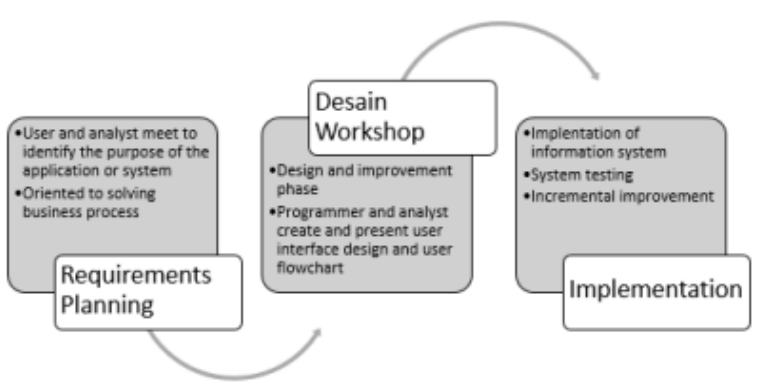

Fig 1. Information systemdevelopment step

1) Requirements Planning

a. User and analyst meet to identify the pupose of the application or system

b. Oriented to solving business process

2) Design Workshop

a. Design and improvement phase

b. Programmer and analyst create and present user interface design and user flowchart

3) Implementation

a. Implementation and application systemtesting 


\section{B. Testing Method}

Black Box is software testing method that is used to examine the extemal work of the system such as the input/ output of the system, the expected results, and the user interface whether the system has been made according to the design [23].

Tabel 1. Black Box Test Form

\begin{tabular}{|l|l|l|}
\hline No & \multicolumn{1}{|c|}{ Function } & \multicolumn{1}{|c|}{ Testing } \\
\hline 1. & Login Process & $\begin{array}{l}\text { Entering the user's email and } \\
\text { password then checking the user } \\
\text { data based on theinput that has } \\
\text { been entered }\end{array}$ \\
\hline 2. & $\begin{array}{l}\text { Internship } \\
\text { Registration } \\
\text { Process }\end{array}$ & $\begin{array}{l}\text { Save data internship to the } \\
\text { database }\end{array}$ \\
\hline 3. & $\begin{array}{l}\text { Internship Seminar } \\
\text { Registration } \\
\text { Process }\end{array}$ & $\begin{array}{l}\text { Save data internship seminar to } \\
\text { the database }\end{array}$ \\
\hline 4. & $\begin{array}{l}\text { Process of } \\
\text { Displaying Data }\end{array}$ & $\begin{array}{l}\text { Fetch and display data fromthe } \\
\text { database to a web page }\end{array}$ \\
\hline 5. & $\begin{array}{l}\text { Process of } \\
\text { Updating Data }\end{array}$ & Perform data updates \\
\hline 6. & $\begin{array}{l}\text { FinalProject } \\
\text { Registration } \\
\text { Process }\end{array}$ & $\begin{array}{l}\text { Save data final project to the } \\
\text { database }\end{array}$ \\
\hline 7. & $\begin{array}{l}\text { FinalProject } \\
\text { Result Seminar } \\
\text { Registration } \\
\text { Process }\end{array}$ & $\begin{array}{l}\text { Save data final project result } \\
\text { seminar to the database }\end{array}$ \\
\hline 8. & $\begin{array}{l}\text { Thesis Defense } \\
\text { Registration } \\
\text { Process }\end{array}$ & $\begin{array}{l}\text { Save data thesis defense to the } \\
\text { database }\end{array}$ \\
\hline 9. & $\begin{array}{l}\text { Process Print } \\
\text { Report }\end{array}$ & Display report \\
\hline 10. & Logout Process & $\begin{array}{l}\text { Delete user session and redirect } \\
\text { to the dashboard page }\end{array}$ \\
\hline
\end{tabular}

\section{RESUlts AND ANALYsis}

\section{A. Design and Implementation of Internship and Final Project Management System}

The implementation of the user interface in the Information System of Intemship and Final Project Management is design-based that had been made by the user. Intemship and Final Project can be accessed using many types of browsers on page https://si.ft.uns.ac.id/portalelektro.

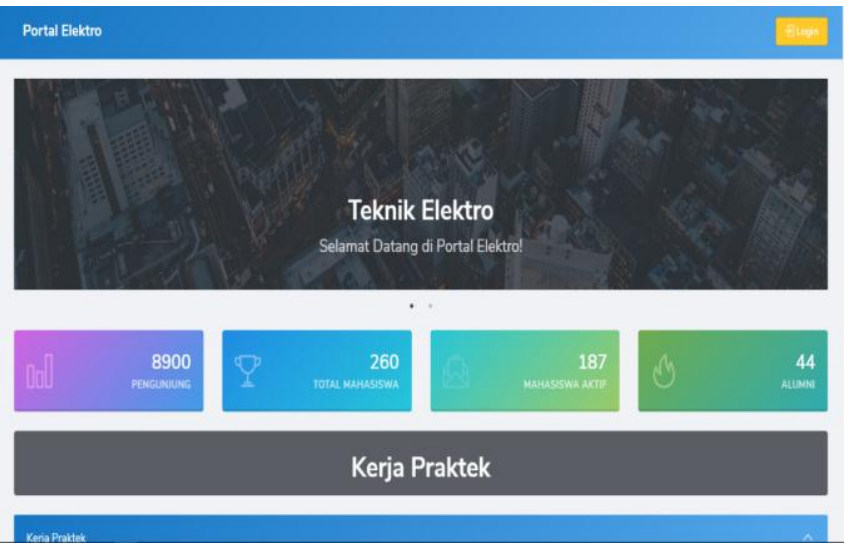

Fig. 2 Dashboard

\section{B. Software Testing using Black Box Method \\ 1) Login Process}

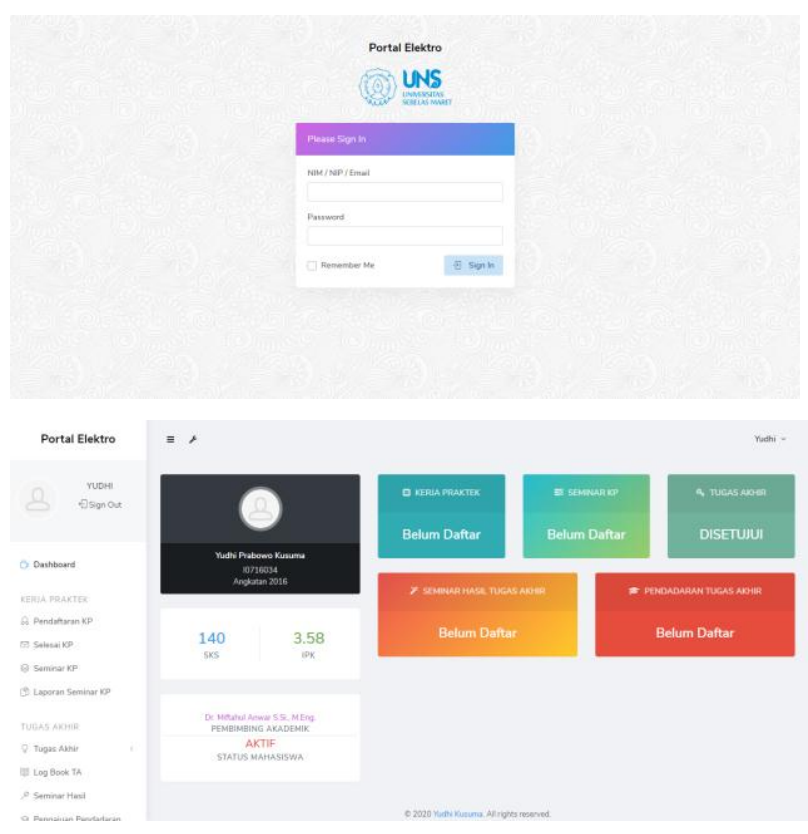

Fig. 3 Login Process

Login Process is the process where the user enters/ in puts the email and pass word into the Login modal and will be redirected to the dashboard page when the user enters the data correctly.

2) Internship Registration Process

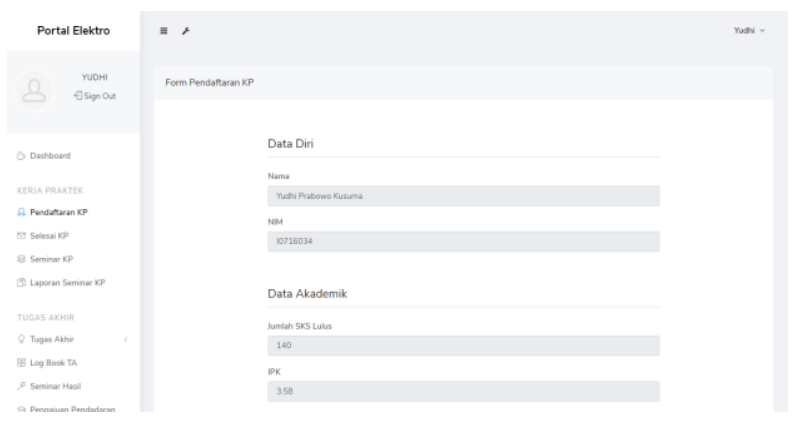




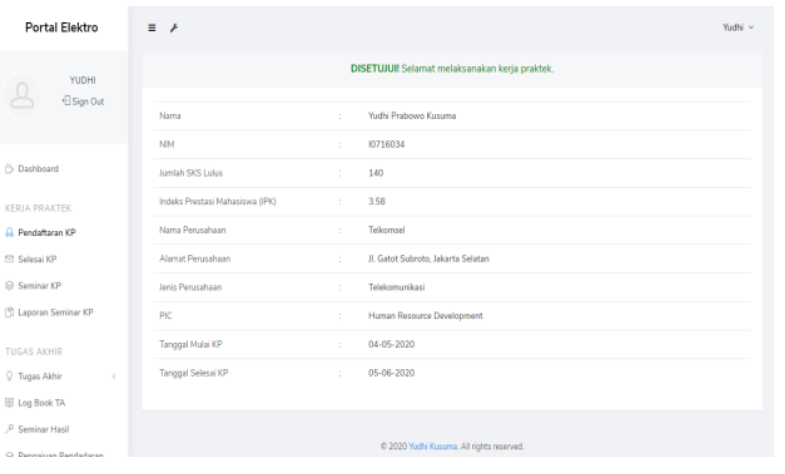

Fig. 4 Internship registration process

Process of Saving DataInternship to the database.

3) Internship Seminar Regis tration Process

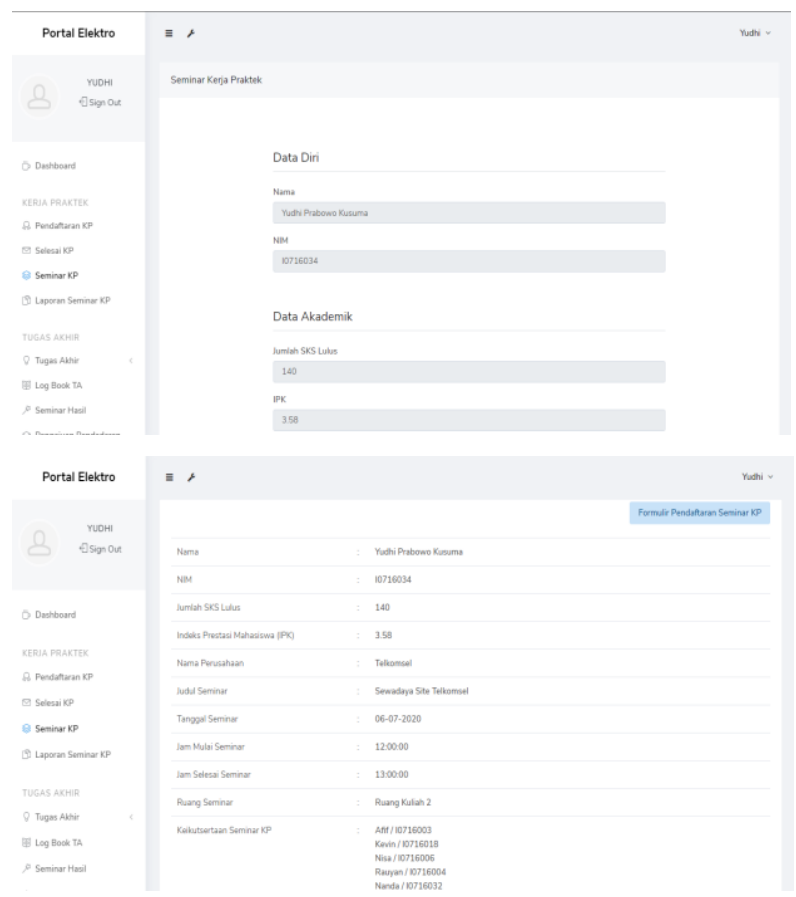

Fig 5. Internship seminar regitration process

Process of Saving Data Internship Seminar to the database.

4) Process of Dis playing Data

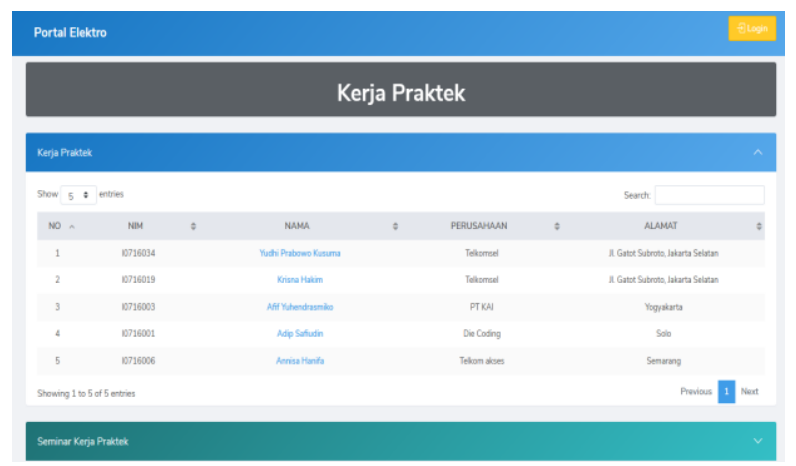

Fig 6. Displaying data

Process of Displaying Data is the process of retrieving data from the database and displaying it on a page on the website.
5) Proces s of Updating Data

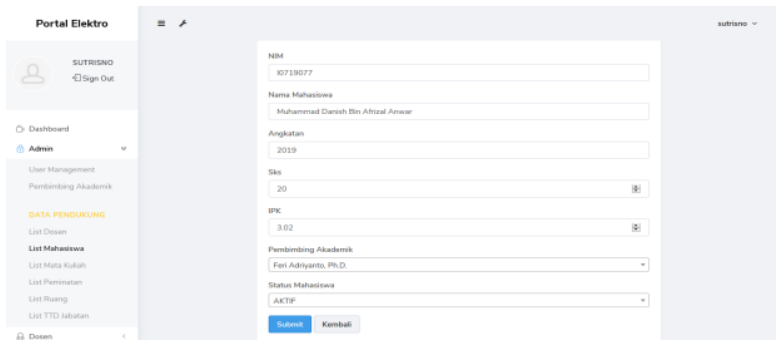

Fig 7. Updating Data

Process of Updating Data is the process changing data and saving it into a database.

6) Final Project Regis tration Process

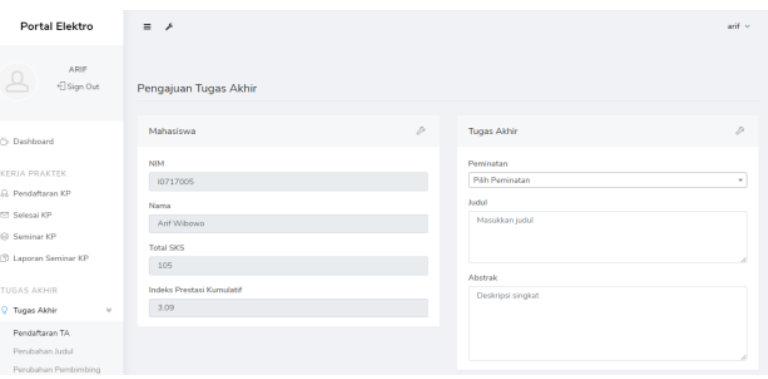

Fig 8. Final project regis tration

Process of Saving Data Final Project Regis tration to the database.

7) Final Project Result Seminar Regis tration Process

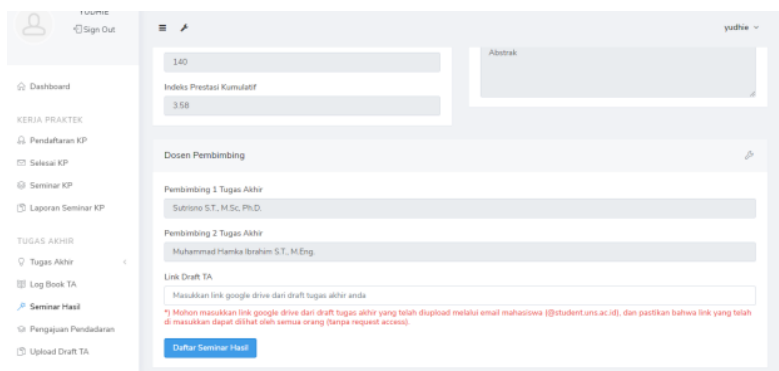

Fig 9. Final project result seminar regis tration

Process of Saving Data Final Project Result Seminar to the database.

8) Thes is Defense Registration Process

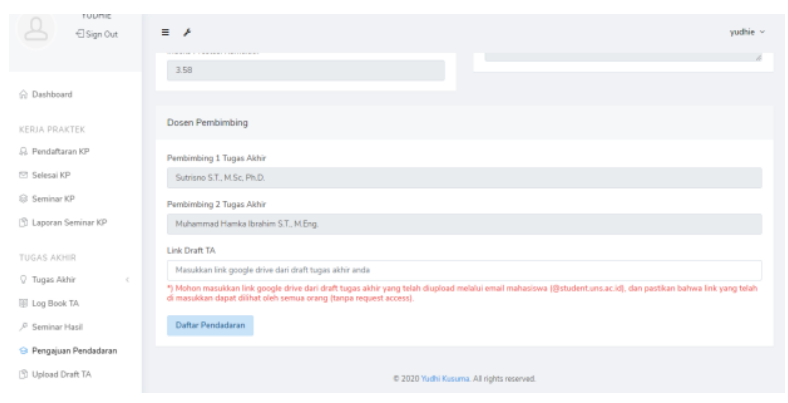

Fig 10. Thesis defense registration

Process of Saving Data Thesis Defense to the database. 
9) Process Print Report
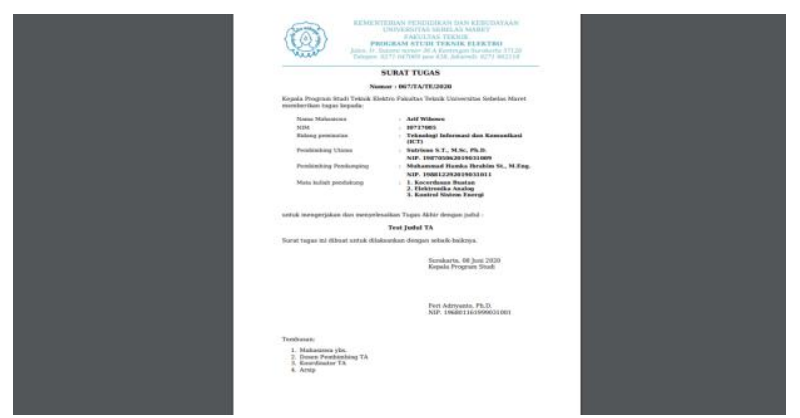

Fig 11. Print report

Process of Dis playing report data.

10) Logout Process

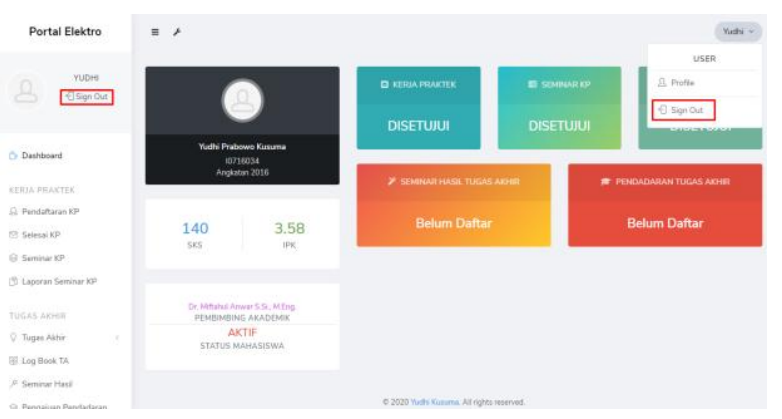

Fig 12. Logout process

Logout Process is the process of leaving the current session, it will redirect the user to the dashboard page.

\section{CONCLUSION}

The Information System of Internship and Final Project Managament System is designed by the user and with several improvements to the system based on user request. The Information System of Internship and Final Project is implemented for real Intemship and Final Project in the Electrical Engineering Study Program. The software testing result to the Information System of Intemship and Final Project using Black Box Testing show that the function of the systems is working properly.

\section{ACKNOWLEDGMENT}

The team expressed the gratitude thanks to the Lecturers of Electrical Engineering Study Program of UNS University for supporting the development of this information system, especially to Mr. Sutrisno S.T., M.Sc, Ph.D, Mr. Muhammad Hamka I. S.T., M.Eng who have acted as the advisors.

\section{REFERENCES}

[1] A. Nakhrowi, A. Riyantomo, and M. S. Mauludin, "Implementasi Framework Laravel Pada Sistem Informasi Pemesanan Penggunaan Lapangan Futsal Berbasis Web Di Zona6 Futsal Semarang," p. 6, 2017.

[2] I. Nugroho, "Sistem Informasi Penerimaan siswa baru Berbasis Web Dengan Php dan Sql," Skripsi, 2011.
[3] D. Karyono, "Perancang an Sistem Informasi Akademik Berbasis Web Menggunakan XAMPP dan Dreamweaver di SMPN 1 Kauman Ponorogo," Skripsi, 2013.

[4] S. Hossain, "Web Application Development With Laravel Framework," p. 34.

[5] C. Supaartagorn, "PHP Framework for Database Management Based on MVC Pattern," Int. J. Comput. Sci. Inf. Technol., vol. 3, no. 2, pp. 251-258, Apr. 2011, doi: 10.5121/ijcsit.2011.3219.

[6] W. Cui, L. Huang, L. Liang, and J. Li, "The Research of PHP Development Framework Based on MVC Pattern," in 2009 Fourth International Conference on Computer Sciences and Convergence Information Technology, Seoul, Korea, 2009, pp. 947-949, doi: 10.1109/ICCIT.2009.130.

[7] M. Laaziri, K. Benmoussa, S. Khoulji, and M. L. Kerkeb, “A Comparative study of PHP frameworks performance," Procedia Manuf., vol. 32, pp. 864-871, 2019, doi: 10.1016/j.promfg.2019.02.295.

[8] Q. H. Nguyen, "Building A Web Application With Laravel 5,” p. 35.

[9] A. F. Ibrahim, N. Musa, and M. N. F. Jamaluddin, "Internship Application System (IAS) for University Students using Laravel," vol. 3, no. 4, p. 7, 2018.

[10] S. Alter, "Defining information systems as work systems: implications for the IS field," Eur. J. Inf. Syst., vol. 17, no. 5, pp. 448469, Oct. 2008, doi: 10.1057/ejis.2008.37.

[11] N. C. Apriyanto, "Sistem Informasi Penjualan Arloji Berbasis Web Pada CV. Sinar Terang Semarang," TI FTI Univ. Pembang. Nas. Veteran, pp. 1-113, 2011.

[12] D. Clark, "Developing Web Applications," in Beginning C\# ObjectOriented Programming, Berkeley, CA: Apress, 2011, pp. 243-263.

[13] B. Raharjo, Belajar Otodidak Framework Code Igniter. Bandung: Informatika, 2015.

[14] A. L. Yudanto, H. Tolle, and A. H. Brata, "Rancang Bangun Aplikasi Sistem Informasi Manajemen Laboratorium Biomedik Fakultas Kedokteran Universitas Brawijaya," J. Pengemb. Teknol. Inf. Dan Ilmu Komput., vol. 1, no. 8, pp. 628-634, 2017.

[15] A. Mishra, "Critical Comparison Of PHP And ASP.NET For Web Development," vol. 3, no. 7, p. 3, 2014.

[16] W. Edy, Z. Ali, and C. Smitdev, Pemrograman Web Berbasis HTML5,PHP \& Javascript. Jakarta: PT Elex Media Komputindo, 2014.

[17] H. T. Sihotang, "Sistem Informasi Pengagendaan Surat Berbasis Web Pada Pengadilan Tinggi Medan," INA-Rxiv, preprint, Aug. 2019. doi: 10.31227/osf.io/bhj5q.

[18] P. Hidayatullah and J. K. Kawistara, Pemrograman Web. Bandung: Informatika, 2014.

[19] Y. A. Binarso and E. A. Sarwoko, "Pembangunan Sistem Informasi Alumni Berbasis Web pada Program Studi Teknik Informatika Universitas Diponegoro," vol. 1, no. 1, p. 13, 2012.

[20] S. Fadli, "Model Rapid Application Development Dalam Pengembangan Sistem Reservasi Dan Penyewaan Kamar Hotel," J. Inform., vol. 1, no. 1, p. 8, 2018.

[21] D. S. Budi, T. A. Y. Siswa, and H. Abijono, "Analisis Pemilihan Penerapan Proyek Metodologi Pengembangan Rekayasa Perangkat Lunak," Teknika, vol. 5, no. 1, pp. 24-31, Mar. 2017, doi: 10.34148/teknika.v5i1.48.

[22] A. Denis, B. Wixom, and R. Roth, System Analysis and Design, 5th ed. United States: John Wiley and Sons, Inc, 2006.

[23] V. Muntihana, “Analisis Dan Perancangan Sistem In formasi Berbasis Web Dan Android Pada Klinik Gigi Lisda Medica Di Kabupaten Bulukumba Sulawesi Selatan,”p. 99, 2017.

[24] L. Moleong, Metodologi Penelitian Kualitatif Edisi Revisi. Bandung: PT. Remaja Yosdakarya, 1998.

[25] D. Y. Prasetyo, "Sistem Informasi Mmanajemen Hotel Arrahman Tembilahan Berbasis Web (Online) Pada Hotel Arrahman Tembilahan," vol. 4, p. 10, 2015.

[26] M. P. Putri, H. Effendi, S. PalComTech, and J. B. R. No, "Implementasi Metode Rapid Application Development Pada Website Service Guide 'Waterfall Tour South Sumatera,"”vol. 07, p. 7, 2018. 